\title{
The Editorial Principles of Anton Federigo Seghezzi and His Giuntina Project
}

\author{
Edward Bowen
}

\begin{abstract}
This essay examines the editorial principles and activity of the Venetian editor Anton Federigo Seghezzi (1706-1743) and investigates especially the construction of his monumental expansion of one of Italy's earliest and most important anthologies of early lyric poetry, the 1527 Giuntina, in his 1731 and 1740 editions of the Rime di diversi antichi autori toscani in dodici libri raccolte.
\end{abstract}

\section{$\mathrm{D}$} URING THE I73OS AND EARLY I740S, A BOOM PERIOD FOR THE printing industry in Italy, literary publishing was dominated by reprints, and buyers sought expanded editions of literary classics. In late 1740, the Venetian dramatist Apostolo Zeno remarked to the Modenese priest and literary historian Ludovico Muratori that "never has so much been printed in Italy" ("non mai si è stampato tanto in Italia"), but he lamented a shortage of serious new authors and a prevalence of disattentive editors. ${ }^{1}$ Among the trusted editors of the time was Zeno's protégé, collaborator, and friend Anton Federigo Seghezzi (1706-1743). Seghezzi's main activity was curating works by Renaissance greats, and during his brief career, from 1728 to 1743, he stood out as one of the most prolific and respected literary editors in the Veneto region. Seghezzi's goal was to save works from obscurity and to "enrich" them, as he states in his preface to Benedetto Varchi's Ercolano,

1. Letter from Apostolo Zeno to Ludovico Muratori, 2 December 1740. Cited in In FELise 1989, 61: "non mai si è stampato tanto in Italia, quanto da pochi anni in qua e che ogni giorno e libri di nuova stampa si veggono e altri per via di associamenti ne vengono minacciati. Ma in tanta copia di stampa, quanta penuria di nuovi autori! Toltone quattro o sei, tutti gli altri sono o disattenti copisti o miserabili traduttori, per li quali l'Italia in luogo di salire e avanzar di credito, va perdendo quel tanto che prima aveva meritato". 
to the point that they would be as inviting to scholars as a limpid stream to a thirsty traveler (Seghezzi 1744, iii-iv). ${ }^{2}$ Seghezzi intended to expand editions' apparatuses by writing prefaces and annotations and by providing indices and additional materials, at times even writing biographies of authors. Much of his editorial activity was driven by Seghezzi's interest in reinforcing the canon and at times in the promotion of lesser-known authors to the canon. His interests were generally in line with those of the Arcadian movement, which favored a return to classic Italian literary models and avoidance of the excesses of the Baroque.

To better understand Seghezzi's agenda of reinforcement and promotion of the canon, this paper contextualizes his editorial career within the ongoing Orsi-Bouhours debate on Italian literature, offering a detailed analysis of one of his boldest projects: the expansion of the 1527 Giuntina anthology, Sonetti e canzoni di diversi antichi autori toscani, in $1731 .^{3}$ A chief aim of this study is to identify the editorial principles of his Giuntina project with a close investigation of the additions he makes to the anthology (a total of 135 poems), how he orders them, annotates them, how he modernizes the poems' language, and finally how he follows and diverts from several paratextual features of the Giuntina.

De Robertis (1977) and Richardson (1994) have both noted how the 1527 Giuntina played a decisive role in the promotion of the canon as it resisted Bembo's praise of Petrarch as the superior poet and sought to elevate the positions of Dante, Cino, and other Tuscan poets. Yet, Seghezzi's decision

2. This volume, published a year after Seghezzi's death, features Ludovico Castelvetro's and Girolamo Muzio's controversial responses to Varchi's Ercolano, a work in which Benedetto Varchi defends Annibal Caro from Castelvetro's criticism of Caro's popular canzone Venite all'ombra de' gran gigli d'oro. In his preface, Seghezzi explains that he not only sought to bring attention back to Varchi's work (first published in 1570) but to also offer greater context for it by providing Castelvetro's and Muzio's responses. Both of these responses had been published posthumously and required editorial work from Gaetano Volpi. For a synthetic discussion of the dispute between Caro and Castelvetro, see Mussio 2007, 406-07.

3. The print edition of the early Italian poets became known as the "Giuntina" after the original publisher of the 1527 edition, the Giunti in Florence (see [SEGNI] 1527). The name of the collection's actual editor, unassigned in the 1527 volume, is credibly confirmed in a marginal annotation by the sixteenthcentury scholar and editor Vincenzo Borghini (1515-1580) in a manuscript of Giovanni Villani's fourteenth-century Nuova Cronica, in which Borghini notes Bardo di Antonio Segni's curation of the 1527 Giunti edition. 
to expand the anthology, and thus to contribute to the development of the canon during his time, has largely been ignored. ${ }^{4}$ Unlike Segni, who heavily relied upon manuscripts to compile the Giuntina, Seghezzi drew all of his additions from print sources, adding poems only by those poets originally featured in the 1527 Giuntina. These decisions come with their own implications for the reinforcement and promotion of the canon, as Seghezzi strengthens Dante's and Cino's positions in the Giuntina, while also elevating figures such as Guido Cavalcanti, Guido Guinizzelli and Giacomo da Lentini. His desire to increase the presence of these latter poets in the volume at times proved less than scientific, especially in the case of Dante, basing attributions on unreliable print sources.

Printed first in 1527 by the Giunti brothers in Florence and again in 1532 by the Da Sabio brothers in Venice, the Giuntina is a selective collection of poems dedicated primarily to Dante and other stilnovists. Of its eleven thin books, the first four showcase Dante's poems, and are followed by books reserved for Cino da Pistoia, Guido Cavalcanti, Dante da Maiano and Guittone d'Arezzo. Book Nine features various Sicilian and Tuscan poets, Book Ten presents canzoni by "autori incerti", and the final book includes "tenzoni", or literary debates, in which the aforementioned poets participated. In 1727, several years prior to Seghezzi's edition, an editor in Florence under the pseudonym of Afoto Aletino (the "unenlightened truthbearer") reprinted the Giuntina. Seghezzi's edition was printed twice in Venice, first by Cristoforo Zane in 1731, and then by Simone Occhi in 1740. Surprisingly, Seghezzi's name does not appear in either edition, but his preface to Ventotto Novelle di Giovanni Boccaccio (1739) attests to the fact that the expanded Giuntina was his project and that he decided upon the additions: "quando avendo io fatto ristampare le Rime antiche di vari Autori, accresciute di tante giunte da me con somma fatica raunate [. . .]" (Seghezzi 1739, ix). ${ }^{5}$

4. Seghezzi's name does not appear in the indices of SAntoro (2008) and InfeLise (1989), and only appears once in Arato 2002 in a footnote (19n). Seghezzi's biographer Pier Alessandro Paravia lamented in 1850: "tolte alcune linee nella Storia della letteratura veneziana dell'ab. Moschini, e un breve articolo nel Nuovo Dizionario storico di Bassano, niuno è dei moderni storici della italiana letteratura che parlato abbia di uno scrittore, che a questa letteratura medesima ha pur renduto non iscarsi servigi" $(1850,64)$.

5. I cite from the 1740 edition of Sonetti e canzoni di diversi antichi autori toscani (seghezzi 1740) as I had access to a copy of it. A careful comparison of both editions demonstrates that the only differences between the two editions are the frontispieces, a small addition to the preface, and a final page noting the 
It is important to situate Seghezzi's agenda as an editor of classic Italian literary works in the light of the Orsi-Bouhours debate on French and Italian literature, which began in the late 1600s, and was still resonant in the 1730s. The controversy was sparked by Dominique Bouhours' Sopra la maniera di ben pensare nei componimenti. . . (1687), in which he praises the noble, or rational, writing of modern French authors and criticizes the excessive ornamental writing of Marino and the artificial nature of Italian pastoral works, including Tasso's Aminta. Many Arcadians at the turn of the century felt the need to defend both the Italian literary tradition and contemporary writing. Giovan Giuseppe Orsi, supported by Muratori, led the charge against Bouhours, and defended Tasso, Guarini and Bonarello in the last two dialogues of Considerazioni sopra un famoso libro franzese intitolato Maniere de bien penser dans les ouvrages d'esprit (1704). Francesco Bruni has argued that Orsi and a number of his followers largely ceded "il territorio barocco", criticizing along with Bouhours the excesses of Tesauro and Marino, but that they held their ground defending Tasso and other writers of the 1500s in an effort to "non restare esclusi dalle modernità e per rilanciare la continuità dinamica della tradizione italiana" (2010, 431). Crescimbeni promoted classic and contemporary Italian poets in his Istoria della volgar poesia (1698). For example, the first five dialogues of "Della Bellezza della Volgar Poesia" in volume six of L'istoria offer extensive praise for the Cosentine poet Angelo di Costanzo (c. 1507-1591) as a poet much admired and imitated by the Arcadians for his Tuscan writing (CREscimBENi [1698] 1730, 6: 1-74). Similarly, Muratori, a strong backer of Orsi's argument, championed the need to find "il buon gusto" in poetic works, praising Petrarch as well as sixteenth-century poets, including di Costanzo. The debate was still alive in Seghezzi's time as Orsi's work was reprinted in Modena in 1735 along with a collection of texts written by his supporters and detractors. ${ }^{6}$ Seghezzi did not edit this work, but that same year he was asked to substitute an editor on the Opere di Torquato Tasso: con le controversie sopra la Gerusalemme liberata (1735-1742). Alessandro Ottaviani asserts that Arcadians who aimed to "promuovere un canone autorizzato" needed new editions of works that were "filologicamente corrette e a circolazione capillare" $(2014,3)$. Seghezzi became a key figure in this effort to

"Licenza de' Riformatori dello Studio di Padova" (Gamba DA Bassano 1839, 244).

6. Considerazioni del marchese Giovan-Gioseffo Orsi Bolognese Sopra la maniera di ben pensare ne' componimenti, già pubblicata dal Padre Dominico Bouhours. . . 1735 . 
enhance editions of classic works, especially as a collaborator of the Zeno brothers and the Volpi brothers.

The Zeno brothers were fundamental in Seghezzi's development. Apostolo Zeno (1668-1750), who apart from being a reformist of melodrama, was a co-founder of both the Accademia degli Animosi in $1691^{7}$ and the important erudite periodical Giornale de' Letterati d'Italia (1710-1727, 1733, 1738-1740) which promoted Italian culture with a reformist approach, especially in the fields of science and literature. ${ }^{8}$ When Apostolo Zeno left Venice in 1718 to work as poeta cesareo in Vienna, his brother Pier Caterino (1666-1732) took over management of the journal. ${ }^{9}$ Following Apostolo Zeno's lead especially, Seghezzi stressed the need for his contemporaries to learn from the great poets. Like Apostolo, he valued his scholarly work more than his own poetry, had great respect for his predecessors' work, and was a thorough annotator of great works (VAN DER LINDEN 2008, 383-410).

Seghezzi made a name for himself with his first few editorial projects, two of which were collaborations with the Zeno brothers. Before working with them, he edited in 1728 the third tome of Opere di monsignor Giovanni della Casa, in which he included his own critical work, Il Tasso, Dialogo d'incerto, sopra lo stile di monsignor della Casa e il modo d'imitarlo. ${ }^{10}$ The

7. This accademia was created as part of the Arcadian movement that spread to the North. Franco Fido states the prime aim of the Arcadi "was a return to the simplicity and good taste of the classics in order to cleanse literature of the artifice and excessive ingenuity of Baroque poetry, of which people were becoming tired" (in Pertile and Brand 1996, 350).

8. Co-founded with Scipione Maffei and Antonio Vallisnieri, Apostolo Zeno managed its first 31 volumes from 1710-1718, publishing three volumes a year. Maffei wrote in his introduction to the Giornale's first volume in 1710: "Egli è pur certo che nulla meglio d'un buon giornale può formar nella mente quella universalità di cognizione, che in uomo di lettere si richiede per non comparire in qualsivolglia materia rozzo affatto ed ignaro; ed egli è certissimo, che saranno un giorno l'opere di tal natura il miglior Tesoro non solo dell'istoria letteraria, ma della scienza ancora e dell'erudizione. . Bisogna aggiungere che in niuna parte più che in Italia sia necessario cotal lavoro, e per la lunghezza del commercio e per la rarità delle corrispondenze d'una parte d'essa con l'altra" (cited in De Michelis 1979, 55).

9. Pier Caterino published one tome per year from 1718 until 1727.

10. Ottaviani points out that from the late 1600 s through the early 1730 s, printing houses in Florence, Venice and Naples had engaged in a 'competition' to produce comprehensive volumes on Giovanni della Casa, whose writing would serve as a model to students at the time $(2014,3)$. 
first large scale project for Seghezzi was his editing, or at least co-editing, of the deluxe four-volume work of Pietro Bembo's Opere, published in 1729 by the active bookseller Francesco Hertzhauser. ${ }^{11}$ Seghezzi's "Annotazioni" of Bembo's Rime in Volume Two point us to moments where Bembo imitated Petrarch, letters in which Bembo discussed his works, opinions by literary critics and even instances where Bembo's successors imitated him. The glosses also offer simple information on editions in which the individual poems were printed. Seghezzi noted at the end of his preface to Volume Two that the Zeno brothers deserved great credit for the success of the edition. Although Apostolo was not regularly present in Venice at this time (he returned permanently in 1731), he collaborated with Seghezzi by contributing a "buon numero delle Rime inedite" from his manuscript collections ([Seghezzi] 1729, 2: preface). In 1730 and 1731, Seghezzi worked simultaneously on two major editions of medieval poetry. His work on the Giuntina anthology, which I will soon discuss in detail, was solely his project. By contrast, his work on the 1730-1731 edition of Crescimbeni's L'istoria del volgar poesia was a collaboration piloted by the Zeno brothers. This group of editors re-ordered the work into five volumes, corrected some errors from earlier editions, and improved numerous annotations. In the preface, Seghezzi is praised as a "giovine di grande espettazione" (CREsCIMBENi 1730, 1: preface [not numbered]).

Despite his work with Seghezzi on several projects, Pier Caterino Zeno was in poor health from 1728 until he died in 1732, and he could not keep afloat the Giornale during these years. The periodical went four years without an issue, and in 1733, Seghezzi edited the first edition, number 38, after this hiatus. He wrote an inspiring preface explaining the importance of both the Giornale and the index he created for its last fourteen tomes, something Pier Caterino had not succeeded in doing from volumes 26 on. With excitement regarding the index, Seghezzi states: "Niuna cosa è

11. Seghezzi's biographer Paravia dedicates a lengthy endnote to this question, listing multiple sources including letters from Giovanni Volpi and also from the Zeno brothers to Seghezzi, congratulating him on his extensive work on the edition $(1850,101)$. Mazzuchelli 1760 writes that the 1729 edition of Bembo's Opere was "sotto la cura principale di Antonfederigo Seghezzi già nostro amico, al quale altri pure prestarono aiuto (186); e della penna di questo sono lavoro le Annotazioni, gl'Indici, e le Prefazioni che si trovano in ciascun Tomo, benché non vi appaia il suo nome, il quale è stato unicamente posto in principio delle sue Annotazioni alle Rime del Bembo che sono in fine del Volume Secondo" (755). 
per mio avviso di maggior giovamento, che il dare il modo a chi legge, in un'opera di varia erudizione ripiena, e in molti libri divisa, di ritrovare senza difficoltà quelle materie che più gli piacciono" (Seghezzi 1733a, [ii]). He also states that Apostolo Zeno was "determinato a ripigliare il filo interotto" (1733a, [iv]); however, that did not happen because of Zeno's other responsibilities and old age. ${ }^{12}$ Nonetheless, the relationship between the two grew after Apostolo's return from Vienna.

The subjects and quality of Seghezzi's early work caught the eye of the Volpi brothers, two editors whose activity in reproposing classic Italian authors was very much tied to the Orsi-Bouhours debate. ${ }^{13}$ From the early 1730 s on, they would guide much of Seghezzi's editorial activity in assigning him projects. Giannantonio (1686-1766) and Gaetano Volpi (16891761) began their activity as printers in 1717 , with the objective, as their biographer notes, to "pubblicare, nella forma che la stampa richieder potesse migliore, opere d'ogni maniera eccellenti, e massime nell'arte del ben parlare, e della più soda eloquenza ed erudizione" (FEDERICI 1809, 8). They sought the aid of Giuseppe Comino, an expert in the printing business, to handle "la materiale direzione" (FEDERICI 1809, 9). This team had proven to be fervent printers of Italian literary classics before Seghezzi began to collaborate with them in 1731. In their first decade of activity they produced editions of Tasso's Aminta (1722), Petrarch's Le Rime (1722), Sannazzaro's Opere volgari (1723), di Costanzo's Le Rime (1723), Caro's Lettere (1725), and Dante's Divina Commedia (1727). The impresa they used for most of their frontispieces - a man who, among ruins, has excavated coins, pieces of statues, and an amphora, and is standing beside a stone with Orazio's motto incised "QVID QVID SVB TERRA EST IN APRICVM PROFERET AETAS" - is an undeniable symbol of Arcadian taste for rediscovery of the past. Roberto Tissoni writes that the undertaking evokes "quello spirito per così dire archeologico che avevano animato il movimento umanistico, e che nel Cinquecento il Bembo e i suoi seguaci avevano esteso agli scrittori volgari" (Tissoni 1993, 11). From 1717 until 1756, the Volpi brothers and Comino produced over 200 editions, mostly literary, that came to be known as Volpi-Cominiane editions (Federici 1809).

12. After another cessation, Stellio Mastraca published the two final volumes of the Giornale de' Letterati d'Italia in 1739 and 1740.

13. Paravia states that it was Seghezzi's work on Bembo's Rime that paved the way for this collaboration $(1850,69)$. It is also worth noting that the same year (1728) Seghezzi contributed Il Tasso for the volume Opere di monsignor Giovanni della Casa, printed by Angelo Pasinello. 
Giannantonio Volpi was a poet in Latin and Italian himself, and a member of the Accademia de' Ricovrati and the Accademia della Crusca. The pastors of Arcadia named him Ulipio Grinejo. He was a noteworthy professor of Philosophy at the University of Padova from 1727 to 1736, and then professor of Greek and Roman letters from 1736 to 1760. In his oration for the new position on 5 May 1736, he denounced harsh critics of Italian literature and he championed contemporary Italian writers. His biographer's summary of the address illustrates how the Orsi-Bouhours debate and the defense of Italian literature were at the center of his Giannantonio's concerns:

Orazione eloquentissima (26), in cui riprovando il sentimento di quegli Italiani, i quali sosteneano che dimentica l'Italia nostra delle pure e native sorgenti, all'estere dar ne dovesse la preferenza, e a quelle ricorrere per attignere i precetti d'ogni sapere, provò chiaramente che il bel paese 'Ch'Apennin parte, e 'l mar circonda e l'Alpe' non solo fu in ogni tempo culla di begl'ingegni fecondissima, ma che lo era all'epoca in cui egli parlava, e che il solo spirito di novità facea apparire bello e meraviglioso tutto ciò che ci veniva dagli esteri tramandato. Dimostrando perciò quanto ingiusto ed ingiurioso fosse al nome italiano cotal sentimento, richiamando alla memoria i letterati d'ogni età che la patria nostra non meno che le straniere nazioni in ogni scienza ammaestrarono, con sode ragioni, e fors' anche col proprio esempio sostenne, che il primo de' mezzi per esiliare dall'Italia la pretesa barbarie quello si era di coltivare la bella lingua de' dotti.

(Federici 1809, 14-15)

Like Orsi, Giannantonio was a strong proponent of Tasso. He translated nine canti of the Gerusalemme liberata in Latin, but dissatisfied with his work, he burned his manuscripts (FEDERICI 1809, 27n).

In 1731, Seghezzi became a regular correspondent of the Volpi brothers, and that year he translated for them La Scacchia by Marcus Hieronymus Vida. They then sought his editorial skills for the volume Opere volgari, e latine del Conte Baldassare Castiglione (1733). A testament to their spirited collaboration appears in an exchange of sonnets printed at the beginning of this volume $e^{14}$ :

14. These sonnets appear directly after a lengthy 27-page dedicatory letter from the Volpi brothers to Cardinal Cornelio Bentivoglio d'Aragona, in which the brothers stress the pedagogical value of this volume: "Avendo noi, per appagare 
Seghezzi to Giannantonio Volpi:

Voi pur col chiaro stile e pellegrino,

Volpi, agli antichi Autor vita porgete;

E lungo il bel Permesso omai cogliete

Servi di Tosco alloro, e di Latino.

Pien di nuovo desir, tutto al divino

CASTIGLIONE lo Studio ora volgete,

Molti togliendo de' suoi Scritti a Lete,

Ove immersi gli avrebbe empio destino.

Quinci lieto a ragion sia che si mostri

Fra la turba de' nobili Scrittori,

A cui luce recaro i sudor vostri;

E altero vada de' novelli onori,

Veggendo eterni i suoi leggiadri inchiostri,

E della pia Conforte i casti amori.
G.A. Volpi replied:

Nel faticoso, alpestro, erto cammino

Per cui verso la Gloria il piè movete,

E a mille chiari spirti esempio siete,

SEGHEZZI, al corso anch'io mi stendo e inchino.

Ma spero indarno a voi farmi vicino,

Che scarco gite, e l'ali al dorso avete.

Se ristando talor non m'attendete,

Cadrò sotto 'l gran fascio oppresso e chino.

Nè potrò rinfrescare à tempi nostri

La fama di Colui che tra' maggiori

Mantova ammira, e di Parnaso i chiostri.

Onde avverrà che IPPOLITA scolori

Per ira il viso, o di vergogna innostri,

E cerchi altr'uom, che sua memoria onori.

(Volpi and Volpi 1733, [xxviii-xxix])

In his opening quatrain Seghezzi underlines the editorial activity of Giannantonio, stating how he brings life to ancient writers and embraces the works in the great Tuscan and Latin traditions. In the second quatrain, he praises Volpi for saving some of Castiglione's works from Lete (from becoming forgotten). Thus, the operation of collecting works and reprinting them helps to eternalize them (v. 13). Volpi's reply not only matches Seghezzi's in rhyme scheme, but also echoes some of the Dantean language which Seghezzi had used. Whereas Seghezzi refers to Lete, Volpi, in his opening quatrain, makes Seghezzi's efforts seem like the climbing of Mount Purgatory: "Per cui verso la Gloria il piè movete, / $\mathrm{E}$ a mille chiari spirti esempio siete". For this reason, Volpi bows to his associate and mentions his vain hopes to be as productive as the diligent Seghezzi who has wings on this back.

l'onesto desiderio degli studiosi, con diligenza, fatica, e spesa non ordinaria, raccolte, ripulite, e date alle stampe l'Opere tutte, così Volgari, come Latine, del Conte BALDESSAR CASTIGLIONE, uomo di eloquenza incomparabile. .." (Volpi and Volpi 1733, [i]). On two occasions in the letter, they thank the erudite Seghezzi for the additions he made to the annotations and for administering "molte e molte notizie" on Castiglione [xxvi]. 
Seghezzi edited two major volumes of letters for the Volpi brothers, those of Bernardo Tasso in 1733 and Annibal Caro in 1735. In both cases, Seghezzi wrote the biographies of these authors accompanied by brief testimonies written by their illustrious contemporaries. ${ }^{15}$ Seghezzi praised both writers as being worth emulating. ${ }^{16}$ For his edition on Tasso, Seghezzi added seven letters and improved the indices of sixteenth-century editions by Giolito. For the latter edition, Seghezzi added a third volume to Caro's letters previously printed by Comino in 1725 . This new volume contains his Vita del Commendatore Annibal Caro as well as 74 letters written by Caro, 42 addressed to him by various people, and 137 of Bishop Giovanni Guidiccioni's letters, mostly written by his secretary Caro.

Of the two biographies, Tasso's includes greater details on his family life, literary achievements and his role as a court figure, while the one on Caro focuses on a bitter exchange between Caro and Castelvetro. Seghezzi dedicates over half of Caro's biography to the debate regarding his Canzone de' Reali di Francia. Seghezzi was not timid in opposing literary historians, in this work and others, but he claimed he did it for a love of truth, not for the sake of doing it $(1735,3$ : ii). Seghezzi criticizes Castelvetro for being overly harsh in his criticism of Caro, and Muratori for being biased in the biography he wrote of his fellow Modenese Castelvetro (1735, 3: xx-xxi). Seghezzi also criticizes Muratori for not providing the sources for his claims, and further argues that support for them cannot be found, even with an extensive search. ${ }^{17}$ To appear less biased than Muratori, Seghezzi states that in

15. He dedicated similar space to both men, 72 pages to Bernardo Tasso's life and 61 pages to Caro's life.

16. For example, Seghezzi considered Caro's Lettere familiari as: "una delle più pregiate scritture di questo rarissimo spirito, ne fanno piena fede le altre sue opere, se non con equale purità di stile dettate, piene così di gentilissimi tratti e d'una felicissima copia di scelte parole, che non solamente e' sembra e nato e allevato in Firenze; ma negli antichi scritti de' soavi parlari interamente consumato" (Seghezzi 1735, 3: ix-x).

17. Seghezzi (1735) writes: "Qui il Muratori scrive che ANNIBALE oltre all'Apologia, pensò a spignere addosso al nemico l'Inquisizione, accusandolo al Tribunale di Roma; e che finalmente gli riuscì di vederlo, dappoichè fu condannato e scomunicato, esule e ramingo fuor della patria, cercar con dubbiosi passi altrove ricetto (a). Io non so donde sieno cavate così risolute notizie, non allegando egli Autore alcuno, presso al quale si leggano, e non avendo io di tal fatto potuto ritrovar vestigio nè fra le Lettere del CARO; nè fra le Opere dello stesso Castelvetro, il quale o nella Risposta all'Apologia, o nella Correzione dal 
"alcune circostanze di questa contesa" he did not entirely trust either of the two authors ("intera fede nè al CARO nè al Castelvetro") because both failed to mention points that were favorable to the other ("quelle cose che sono favorevoli all'avversario" [1735, 3: xxii-xxiii]).

By 1735 Seghezzi's reputation was solidified and his experience in promoting Italian writers and revisiting Italian literary history must have been appealing to the printer Stefano Monti, who needed a substitute editor for the project entitled Delle opere di Torquato Tasso con le controversie sopra la Gerusalemme liberata. Bonifazio Collina, under the pseudonym Giuseppe Mauro, started this large project in the early 1720s, but only succeeded in publishing the first volume in 1722. Over the next seven years Seghezzi would carry the twelve-volume collection to completion, enriching it by adding letters and poems obtained from Muratori and Apostolo Zeno. Collina's long preface was maintained for the 1735 reprint of Volume I. In it, Collina praises Tasso, addresses his French critics Boileau, Rapin, and Bouhours, and concludes that Orsi and his followers had won the debate:

Il primo, e principale mio intento, come già v'ho detto, è stato il mostrare quanto abbia potuto un solo ingegno Italiano eseguire di grande, e di portentoso poetando, e filosofando; e quanto l'Italia abbia in un solo, onde vantare la sua gloria nel gran pregio dell'Eloquenza. Veggano un poco i Franzesi, fra quali vi è stato in questi ultimi tempi chi ha ardito di mettere in deriso il Tasso dialogizando, senz'avere alcun riguardo alla grandissima, e somma riputazione, in cui da tutt'altre Genti è stato sempre tenuto; veggano quanto sia il Tasso; e leggano in fronte a' suoi libri un nome che può loro ingerire non solo riverenza, ma soggezione, cioè il vostro; poiche ove con Voi hanno voluto cimentarsi movendo contrasto del maggior grido delle Lettere fra la nostra, e la loro Nazione, han sempre perduto.

(Delle opere di Torquato Tasso 1735, 1: xxiv)

Though Seghezzi did not write this preface, his direction of the project demonstrates an active role in the defense of Italy's canon.

During the years that Seghezzi worked on this project, he also curated the fifth edition of Angelo di Costanzo's Rime (1738) for the Volpi brothers. In Seghezzi's dedication of the new edition to his close friend Gasparo

Dialogo delle lingue del Varchi, o altrove, dovrebbe averne fatta menzione; nè appresso altro scrittore contemporaneo o posteriore al CARO" (3: xxxi). 
Gozzi, he criticizes those contemporaries who are no longer used to the hard work of gathering gems written by "antichi maestri" $(1750,4) .{ }^{18}$ Seghezzi's intervention was mainly in the second half of the edition, where he added 34 poems by Galeazzo di Tarsia, a fellow Cosentine of di Costanzo. The second part also has its own dedication, this time to Gian-Grisostomo Trombelli, in which Seghezzi claims to have added all the poems he had at his disposal by Galeazzo. Just as Seghezzi had criticized Muratori in his previous work, here he questions both Crescimbeni's historiography and declaration that Galeazzo influenced di Costanzo. ${ }^{19}$

Seghezzi's last editorial project before he died was a collaboration with the Volpi brothers on a reprint of Varchi's Ercolano. A major reason for Seghezzi's interest in Varchi was that he was a close correspondent of Caro and had defended Caro in the 'contesa' with Castelvetro. In his ten-page preface to the volume, Seghezzi addresses the unjust criticism of Varchi's work by Muzio and Castelvetro. This 1744 edition is a reprint of a 1730 edition printed in Florence that included a biography of Varchi, testimonials and an index. Two motivations for the reprint are that the 1730 edition has a page turned upside down, and also Gaetano Volpi wanted to include a faithful transcription of Castelvetro's Correttione di alcune cose del Dialogo di Varchi (publ. posthumous, in 1572). Seghezzi praises Volpi's diligence in transcription and improving the index, and he demonstrates some humor in stating that Volpi's efforts could be called "Correzioni delle Correzioni dell'Ercolano di M. Benedetto Varchi" (1744, xi). ${ }^{20}$

18. I have cited the 1750 edition, but it includes the original preface from the 1738 edition.

19. Seghezzi argues that this was highly unlikely and that the two poets had very different styles: "nè io veggio che le rime d'esso GALEAZZO abbiano cosa alcuna di somigliante nell'ordine e nel conchiudere a quelle del COSTANZO: che scrisse, come ognun può vedere, in un modo del tutto diverso" $(1750,156)$.

20. "La istancabile diligenza però del Signor Don Gaetano Volpi vinse finalmente ogni malegevolezza, col trascrivere ch'egli fece tutto di sua mano il Castelvetro, non volendo che si diformasse nella Stamperia, com'è solito, il rarissimo esemplare di Basilea, e collo sterpare nel libro di lui e del Muzio sì rea gramigna, col distinguere le citazioni con diversità di caratteri, col bene interpungere, e ridur tutto a miglior ortografia, col riordinare, ed accrescere notabilmente l'Indice del Castelvetro [. . . ]" (Seghezzi 1744, xi). 


\section{The Giuntina Project}

This cursory view of Seghezzi's editorial agenda to promote Italy's classic writers and provide researchers with helpful glosses, additional material and indices, helps us to understand why Seghezzi would have wanted to expand the Giuntina. Two centuries had passed and only Aletino had reprinted it with some minor corrections to the language and order. It seems odd that Seghezzi would not have known about Aletino's edition (1727), but he shows no signs of utilizing it and he does not mention it anywhere in his edition (GAmba da Bassano 1839, 245). Had he known about Aletino's edition, it seems likely that he would have set his edition apart from it in his preface.

Nonetheless, it is worth stating that the two men shared an Arcadian mindset regarding the utility of classic works and the need to save them from obscurity. Aletino states that he could speak at length about the Giuntina's value: "la rarezza, la sublimità, l'utile onesto e copioso, il nobil diletto, e gli altri pregi tutti, che adornano, o che accompagnano questo, comechè picciol, volume" $(1727,3)$. Seghezzi praises it as well, exclaiming "quanto di riputazione alle lettere Toscane apportasse la pubblicazione del rarissimo esemplare" $(1740,2 \mathrm{r}-2 \mathrm{v})$.

Aletino and Seghezzi shared several editorial principles, two of which were related to their respect for the Giuntina anthology. First, they maintained all of the poems of the original. Even though Seghezzi added poems, he states "non abbiamo levato nulla, essendosi interamente seguiti i vestigi della prima impressione" (1740, 2v). Second, they both praised Bernardo Giunta's preface and reprinted it in their editions. Third, they aimed to improve the work with corrections and an expanded apparatus.

Aletino reprinted the Giuntina with its poems "diligentemente ricorrette" with an additional preface, an "avviso al lettore", and an appendix showing some variants of Dante's poems ([A letino] 1727). ${ }^{21}$ Aletino announces that he corrected errors in particular verses, and that he cleaned up punctuation and spelling "a più sano giudizio" (1727, 11r). Regarding accents and apostrophes, he claims to not have followed "i Moderni" for two reasons: to avoid too great of a task and to "lasciare alcuno essempio della sempre veneranda antichità" $(1727,11 r)$. He removed those that could "produrre ambiguità, ed inviluppo, ed all'incontro aggiunto quelli, che mi son paruti necessari" $(1727,11 \mathrm{r})$. His goal was to facilitate the reading of the poems. As I will discuss later, Seghezzi made some minor corrections

21. See the frontispiece for the quote "diligentemente ricorrette". 
to the orthography of the Giuntina and greater changes to the poems he drew from other sources. Both editors saw the need for an index, but only Seghezzi succeeded in creating one. In his preface, Aletino claimed that he had hoped to offer detailed annotations for the "luoghi difficilissimi" in the poems, and also add a glossary, but he laments: "l tempo, e le circostanze non me l'anno permesso" $(1727,11 v)$.

One intervention that Aletino made, which Seghezzi avoided, was to reorder the poems in Books One and Two by genre as the Giunti had ordered the last nine books. This was part of his plan to 'rinnovare' the Giuntina, enforcing a principle that was followed in most of the original anthology: "Al quale effetto, veggendo, che ne' due primi libri, non come negli altri in appresso, ma alla rinfusa Sonetti, e Canzoni eran posti, mi ho preso la briga di ordinargli nella stessa maniera" ([Aletino] 1727, 10v). In Book One, Aletino re-ordered the poems of the Vita nuova by genre; a modification that Seghezzi likely saw as too aggressive. Seghezzi approached the ordering of the poems differently. When he added poems to the anthology, he made it a point to insert those of a certain genre at the end of the sections ordered by genre in the Giuntina. However, when he created a new book for poems by Cino da Pistoia, he did not order these by genre.

Seghezzi's glosses are another distinguishing feature of his edition. He mainly uses glosses to state where he drew his attributions from, and occasionally he states how other editors' attributions differ from his. This feature allows his work to serve as a reference copy to students and other scholars of Tuscan and Sicilian poetry. When a sequence of poems is drawn from one source, Seghezzi's often puts a gloss at the start of this series but does not tell us that it is meant to apply to other poems.

\section{Seghezzi's additions to the Giuntina}

Where Seghezzi and Aletino differed most involved the question of emending and adding texts. Aletino humbly admits that the Giuntina is a better edition than he could create on his own and that he did not create a new collection because he wanted to avoid dealing with corrupt sources of poems:

se io, o avendo a quella fatta poscia in Vinegia la mira, o eziandio se, proccurati altri testi a penna (che lo più delle volte, o adulterati, o pieni d'infiniti errori ritrovansi, e talora men che fedeli) ti avessi porta una nuova non più veduta edizione: e d'altra parte non ho io voluto entrar 
mallevadore di tutti que' luoghi malagevoli, ed oscuri, che sparsamente qui leggonsi[.]

Seghezzi, like Aletino, also notes this challenge in his preface, but explains that by consulting the best sources - "la scorta sicura de' migliori testi" he made sound textual additions ([SEGHezzI] 1740, 2v).

Seghezzi's 135 additions increased the original volume of 289 poems by nearly 50 per cent. He only added poems by the poets featured in the original Giuntina, favoring especially Dante and Cino da Pistoia, of whose works he created new books. Further, he greatly reduced the number of unattributed poems, reassigning 11 of the 15 poems in Book Ten by 'Autori Incerti' to Dante and Cino. The sixteenth-century editions of poetry Seghezzi drew from include Guglielmo di Monferrato's 1518 edition of Dante's Rime and Niccolò Pilli's 1559 edition of Cino da Pistoia's poems ([Seghezzi] 1740, $2 v$ ). Seghezzi also greatly expanded the book of poems by 'antichi autori' with significant addenda attributed to Cavalcanti, Guinizzelli, Giacomo da Lentini and Fazio degli Uberti. For these he relied on La bella mano by Giusto de' Conti (printed by Jacopo Corbinelli in 1595) and Leone Allacci's Poeti Antichi (1661).22

Seghezzi's decision to draw poems exclusively from print sources makes his operation mainly one of canon reinforcement, but it is possible to also view it as a form of canon promotion, considering that he elevates the role of certain poets within a reputable anthology. In his preface, Seghezzi praises the value of all the poems, but champions three poets in particular: "sì sono eglino al tutto di leggiadri pensieri fecondi, e principalmente Dante Alaghieri, Cino da Pistoia e Guido Cavalcanti, i cui versi ripieni sono senza fallo alcuno di vaghissimi detti, e di una maravigliosa dolcezza" (1740, 4r). Near the end of his preface he reflects on the important additions made to Cavalcanti, Guinizzelli, and Uberti, explaining how with more poems by them in the Giuntina it will be easier to see how great of poets they were:

e se maggior numero delle rime de' duo Guidi, dico del Cavalcanti e del Guinizzelli, e di Fazio degli Uberti non ci avesse invidiato la età, noi più apertamente vedremmo, quanto gentili e felici sieno stati que'

22. La bella mano is a collection of poems written by Giusto de' Conti in the midfifteenth century. Corbinelli printed an edition of it in 1595 along with a "Raccolta di antiche rime di diversi toscani". In 1715, a reprint of Corbinelli's edition was published in Florence. 
primi tempi, i quali da alcuni e poveri, e rozzi, e forse di barbarie ripieni vengono giudicati; ma perchè nella seguente elegantissima prefazione di Bernardo di Giunta compiutamente sopra ciò si ragiona, noi dal più oltra favellare ci rimarremo. $(1740,4 \mathrm{r})$

The major goal of Bernardo Giunta's preface was his call for contemporaries to recognize the beauty in the poetry that came before Petrarch, but in truth, the original Giuntina had reserved little space for the Sicilians and other early poets such as Guinizzelli, Bonagiunta and Fazio. Thus, in this light, Seghezzi's decision to elevate their presence in the anthology makes it possible to consider his work canon promotion, and not simply reinforcement. Undoubtedly, had he searched through manuscripts instead of print sources to find additional poems by certain poets, his work would have been a more active form of canon promotion.

Just as Aletino had feared the reliability of print sources, Seghezzi also had his reserves. One of the main sources he drew poems from, but with caution, was Allacci's Poeti Antichi. In his preface, Seghezzi criticizes Allacci directly:

io non posso rifinire di maravigliarmi della negligenza soverchia di quel Raccoglitore nel dare alla luce que' pregevolissimi avanzi della Toscana antichità. Di Jacopo da Lentino dunque, e di Guido Orlandi, e di Guido delle Colonne, e di Cino da Pistoia, e di Guittone d'Arezzo e di Onesto Bolognese si leggeranno nell'Allacci parecchie composizioni, che ora non si sono ristampate: avendo noi scelte solamente quelle, le quali parute ci sono meno manchevoli e imperfette e non pertanto si veggiono in molti luoghi miseramente corrotte. $(1740,3 r)$

Here, Seghezzi makes it clear that a significant part of his selection process was based on reliability. He left out the poems in Allacci's anthology that he saw as corrupt, "che a loro Autori loda alcuna non apporterebbono" $(1740,3 r)$. His statement illustrates that he was rather selective and did not simply add everything at his disposal. He wanted the poems added to improve the reputation of poets, certainly not to hurt them.

The following table (Table 1) illustrates how Seghezzi enlarged the Giuntina and where the major additions were made. 
Table 1. Differences in Structure and Poem Count: Original Giuntina vs. Seghezzi's ed.

\section{7 / 1532 Giuntina}

Book I Dante, 31 poems (sonetti, canzoni, ballate)

Book II Dante, 30 poems (sonetti, ballate, canzoni)

Book III Dante, 9 canzoni

Book IV Dante, 6 canzoni

Book V Cino, 48 poems

(41 sonnets, 4 ballate, 2 sonnets, 1 canzone)

Book VI Cavalcanti, 26 poems

(13 sonnets, 12 ballate, 1 canzone)

Book VII Da Maiano, 47 poems

(39 sonnets, 5 ballate, 3 canzoni)

Book VIII Guittone (34)

(30 sonnets, 1 ballata, 3 canzoni)

Book IX “Canzoni e Ballate Diversi Autori” (12)

(9 canzoni, 3 ballate, not in this order)

Book X "Canzoni antiche di autori incerti" (15)

(13 canzoni, 2 sestine)

Book XI "Sonetti de i sopradetti autori Mandati l'uno all'altro"

(31 sonnets)

\section{1/40 Seghezzi}

Book I Dante, same (31)

Book II Dante, same (30)

Book III Dante, same (9)

Book IV Dante, same (6)

Book V Dante (15 total)

5 sonnets from outside sources

9 canzoni from 1532 Book IX 'autori incerti'

1 epigram from Crescimbeni

Book VI Cino, same (48)

Book VII Cino (68 total)

(not in the following order)

49 sonnets, 14 canzoni ( 2 are from Book IX

'autori incerti')

2 ballate, 1 sestina, 1 satira

1 ten-verse poem

Book VIII Cavalcanti (32 total)

(19 sonnets, 12 ballate, 1 canzone)

Book IX Da Maiano, same (47)

Book X Guittone (36)

(32 sonnets, 1 ballata, 3 canzoni)

Book XI "Canzoni, Sonetti, e Ballate di Diversi

Autori" (56)

Adds 44 poems to original 12 (See Table 2)

Book XII "Canzoni antiche di autori incerti, e sonetti di diversi mandate l'uno all'altro" (46 total)

2 canzoni from original Book X

2 sestine from original Book X

31 sonnets from Book XI

11 additional sonnets from outside sources 


\section{Dante Alighieri}

Seghezzi strengthens Dante's position as the showcased poet in the Giuntina by adding an entire book of fifteen poems (five sonnets and ten canzoni) to his corpus. The new Book Five, entitled "Sonetti e Canzoni di Dante Alighieri", begins with the five sonnets along with marginal notes indicating Seghezzi's sources:

O Madre di virtute, luce eterna,

Di donne io vidi una gentile schiera

Quando il consiglio degli augei si tenne,

Un dì si venne a me melanconia, Messer Brunetto, questa pulzelletta
"Dalla Raccolta del Corbinelli"

"Dal Libro I della Perfetta Poesia del Muratori"

"Dalle Annotazioni del Redi sopra il Ditirambo"

"Dalla Raccolta di Allacci"

[here, there is no postilla, but the source is Allacci]

De Robertis attributes four of these sonnets to Dante and O Madre di virtute, luce eterna to Antonio Da Ferrara (De Robertis 2002, 2.2: 1085).

Seghezzi's Book Five closes with ten canzoni, nine of which he draws from Book Ten of the Giuntina (which consists only of thirteen canzoni of uncertain attribution). For this section, Seghezzi takes only one poem, $\mathrm{O}$ $t u$, che sprezzi la nona figura, from an outside source: Crescimbeni's Commentari [. . .] intorno all'Istoria del volgar poesia (1730). ${ }^{23}$ Moving poems from the book of "autori incerti" here means that Seghezzi attempted to reduce uncertainty in his edition, while at the same time promoting Dante. Seghezzi relied on Monferrato's 1518 collection of Dante's Rime, claiming he consulted manuscripts as well for these attributions but does not cite them by name or shelf mark: "in essa sono attribuite a Dante, sotto il cui nome le abbiamo altresì ritrovate in alcuni ottimi manoscritti, a lui volentieri si sono date, a cui più che ad altri per lo stile, e per lo sentimento ci pare, che si appartengano" ([SEGHEzzI] 1740, 2v). In his marginal notes he only mentions Monferrato's edition in the first gloss, but this is presumably meant to apply to all.

Io miro i crespi e gli biondi capegli,

"Dalle Canzoni e Madrigali di Dante, 1518. Nelle Rime antiche si trova sotto il nome d'Incerto questa Canzone"

23. Gabriele Rossetti also ascribed this epigram to Dante in his Il mistero dell'amor platonico in 1625, though Seghezzi only mentions Crescimbeni as his source. 
La bella stella, che il tempo misura

Perchè nel tempo rio

Giovene donna dentro al cor mi siede,

Dacchè ti piace Amore, ch'io ritorni
"Questa Canzona si legge nelle rime antiche fra le rime degli incerti Autori: e nelle rime di M. Cino, raccolte dal Pilli"

"Nelle Rime antiche questa Canzona è di Autore incerto, e dal Pilli fu attribuita a M. Cino"
"Questa canzone hassi fra le Rime antiche come cosa d'Autore incerto"

"Questa Canzona fu stampata fra le Rime degli Autori incerti nelle Rime antiche, e fra le rime di M. Cino"

L'uom, che conosce, è degno, ch'aggia ardire, "Nelle Rime antiche questa Canzona è attribuita ad Autore incerto, e dal Pilli a M. Cino".

Io non pensava, che lo cor giammai

L'alta speranza, che mi reca Amore,

Oimè, lasso, quelle trecce bionde,

O tu, che sprezzi la nona figura,
"Questa Canzona si trova sotto il nome di Autore incerto nella Raccolta del 1527"

"Il Pilli e il Corbinelli fanno Autore di questa Canzona M. Cino”

"Nelle Rime antiche sotto il nome d'incerto fu impressa questa Canzona, che il Pilli attribuisce a M. Cino"

"Dal Vol. I de' Com. del Crescimbeni"

From Seghezzi's glosses, we also learn that six of the added canzoni are attributed to Cino by Pilli in his 1559 edition of Cino's Rime. ${ }^{24}$ Seghezzi announced this discrepancy in his preface: "Se altri poi leggendo le Rime

24. These six poems include: La bella stella, che il tempo misura; Perché nel tempo rio; L'uom, che conosce, è degno, ch'aggia ardire; Lalta speranza, che mi reca Amore; Oimè, lasso, quelle trecce bionde; Dacchè ti piace Amore, ch'io ritorni. Contin I 
di Cino da Pistoia pubblicate dal Pilli, vedrà che alcune cose da noi non a Cino, ma a Dante vengono ascritte, sì dovrà egli sapere, che abbiamo seguita l'autorità della Raccolta del Giunta, e degli altri testi, che facevano autore di que' versi lo stesso Dante" (1740, 3r).

But how could the Giuntina, which lists these poems as of "uncertain attribution" help Seghezzi make attributions to Dante? Seghezzi's confusing language, here coupled with his reference of unnamed manuscripts, makes this a messy moment. His main source, Monferrato's edition, would later be attacked in 1834 by Pietro Fraticelli in his edition of Dante's Rime: "Vero è che col nome del nostro poeta vedesi stampata nella veneta edizione delle Rime antiche del 1518, sulla cui sola autorità la riprodussero poscia il Pasquali, lo Zatta ed altri; ma questa edizione pei tanti suoi strafalcioni e inesattezze non merita alcuna o ben picciola fede" (Fraticelli 1834, cciv). Fraticelli's criticism is also supported by De Robertis's 2002 critical edition, which labels all ten of these canzoni "non dantesca". This gross error of attribution in his new book reveals a reckless reliance on a printed source, and it suggests an overzealous push to both reduce uncertainty and promote Dante, likely in hopes of making his book more appealing to buyers.

\section{Cino da Pistoia}

Seghezzi did not alter Book Five of the Giuntina, aside from changing its title simply to Book Six, leaving the same poems in the same order (41 sonnets, four ballate, two more sonnets, and a canzone). His additions to the corpus of Cino da Pistoia in his new Book Seven were of greater number and from a more reliable source than those he made to Dante. Seghezzi placed 68 poems by Cino in Book Seven, making it the book with the most poems in the edition. Pilli's work proved to be a reliable source for these additions, as Enrico Bindi and Pietro Fanfani attribute all of these poems to Cino in their 1878 edition Le rime di Messer Cino da Pistoia.

Notably Seghezzi no longer follows the principle of having brief "books" (units) of similar size in the Giuntina. While the books that Seghezzi did not alter occupy around 21 pages each in his 1740 edition, his new Book Seven takes up 53 pages (135-87), making it only second in length to the other book to which he made numerous additions, Book Eleven, "Canzoni,

1946 and Santagata 2011 do not include these poems in their editions of Dante's poetry. 
sonetti e ballate di diversi autori", consisting of 56 poems occupying 66 pages (1740, 269-335).

Seghezzi's Book Seven is not ordered neatly by genre, another principle that the Giunti brothers' largely adhered to in their anthology. The haphazard order of Seghezzi's new book is as follows:

5 sonnets; 1 canzone, 1 ballata, 9 sonnets, 1 canzone, 1 ballata, 5 sonnets, 1 canzone, 1 sonnet, 1 canzone, 1 sonnet, 3 canzoni, 4 sonnets, (a 10 verse poem), 2 canzoni, 7 sonnets, 1 canzone, 7 sonnets, 1 satira, 1 canzone, 1 sonnet, 2 canzoni, 9 sonnets, 1 canzone.

The majority of Cino's poems in Book Seven are sonnets; a total of 49. There are fourteen canzoni, two ballate, one sestina, a satira and a tenverse poem. Despite Seghezzi's decision to not honor Pilli's attributions of six canzoni by Cino in his new Book Five dedicated to Dante, he utilized Pilli's work from 1559 as the major source for his new Book Seven: "A Cino da Pistoia si sono accresciute notabilmente le Rime, essendosi spogliata la rarissima e unica edizione, che Niccolò Pilli pubblicò in Roma nel 1559, col cui aiuto molti e gravi errori si sono felicemente levati" (1740, 2v). Two canzoni from the Giuntina's Book Ten ("Autori incerti") are now attributed to Cino in Seghezzi's new Book Seven: Quando io pur veggio, che sen vola il sole and Io non posso celar il mio dolore. His glosses in Book Seven note he drew the final sestina from La bella mano.

\section{Guido Cavalcanti}

Seghezzi's Book Eight adds six more sonnets to the corpus of Cavalcanti. Book Six of the 1527 Giuntina, the first printed book of Cavalcanti's Rime, is neatly divided by genre. It begins with thirteen sonnets, which are followed by twelve ballate and one canzone. Seghezzi inserted the six sonnets directly after the first thirteen. His chief source for these attributions was the 1715 Bella mano di Giusto de' Conti upon which he relied for five attributions (Avete in voi li fiori e la verdure, Ciascuna fresca e dolce fontanella, Beltà di Donna, e di saccente core, Novelle ti so dire, odi Nerone, Certo non è dall'intelletto accolto). The sixth additional sonnet Veder potesti, quando voi scontrai was confirmed by Allacci's collection. Of the six sonnets Seghezzi added, all of them are confirmed by De Robertis (1986) and Favati (1957) as belonging to Cavalcanti. I will discuss later how Seghezzi also elevated Cavalcanti's role in Book Twelve, which includes literary debates ("tenzoni"). 


\section{Books Nine and Ten: Dante da Maiano and Guittone}

Dedicated to Dante da Maiano, Seghezzi's Book Nine comes straight from the Giuntina's Book Seven with no additions. It includes 39 sonnets, 5 ballate, and 3 canzoni. In her critical edition of Dante da Maiano's poetry, Rosanna Bettarini (1969) attributes all of these 47 poems to him.

Seghezzi only added two poems to the subsequent book devoted to Guittone D'Arezzo. The original Giuntina contains 31 sonnets and 3 canzoni by the famous thirteenth-century poet. Seghezzi remained faithful to the medieval practice of ordering by genre inserting the two additional sonnets after the original 31. He drew the sonetto rinterzato $\mathrm{O}$ benigna, o dolce, o preziosa, from Redi's Bacco in Toscana and the sonnet Uomo fallito pien di van pensieri from Allacci's collection.

There was not an extensive collection in print of Guittone's work upon which Seghezzi could have relied, even though Allacci's volume contains five additional poems. ${ }^{25}$ There is no significant evidence to support the notion that Seghezzi followed Dante's lead, in the De Vulgari Eloquentia and in the Commedia, in downplaying Guittone's importance as a poet.

\section{Book Eleven: Sonnets by various Tuscan and Sicilian poets}

While Seghezzi's additions to Dante, Cino and Cavalcanti only strengthen their privileged role in the Giuntina, his additions to certain poets in Book Eleven elevate their positions. First and foremost, we should recall that Book Nine of the 1527 Giuntina only featured twelve poems, all by different poets, suggesting that no poet in particular had a privileged role in the book. Seghezzi adds 44 poems to Book Nine, entitled "Canzoni, Sonetti, e Ballate di Diversi Autori", but he does not distribute his additions equally. Given his editorial principle of drawing from print sources, it is understandable that he could not add extensively to all of the known works of these poets. The following table (Table 2) lists Seghezzi's additions to this book of the Giuntina and it identifies the print sources that he drew these

25. In Allacci, the six poems attributed to Guittone are: Tutor s'eo veglo o dormo, Homo ch e sazo non a cor lizero (Seghezzi's wrongly claims in his glosses that Allacci attributed this to Guinizzelli), Homo salito plen de van penseri, Tempo ven che sale, e che sendere, Giudice Ubertino in ciascun fatto, Credo farete ben misser honesto (Allacci 1661, 385-92). 
additions from. The fourth column illustrates that the large majority of these attributions have been confirmed by twentieth and twenty-first century scholars, yet in a few cases there are discrepancies. A key for abbreviations is provided at the bottom of the table.

Table 2. Seghezzi's additions to the book titled "Canzoni, Sonetti, e Ballate di Diversi Autori"

\begin{tabular}{|c|c|c|c|}
\hline Giuntina 1532 & Seghezzi's expanded edition & $\begin{array}{l}\text { His } \\
\text { Source }\end{array}$ & $\begin{array}{l}\text { Modern } \\
\text { Edition }\end{array}$ \\
\hline
\end{tabular}

Franceschino degli Albizi

Per fuggir riprensione

Per fuggir riprensione

G

S52

Fazio

Lasso; che quando imaginando vegno

Lasso, che quando immaginando vegno

G

S52

Di Superbia

A S52

D'Avarizia

A

S52

D'Invidia

A $\quad S 52$

Di Lussuria

A

$\mathrm{S} 52$

Di Gola

S52

D'Ira

A

S52

D'Accidia

A

Io guardo infra l'erbette per li prati,

A

A M. Antonio da Ferrara

BM

C52

Ser Lapo Gianni

Per me credea, che 'l suo forte arco Amore

$\mathrm{BM}$

Amor nuova, ed antica vanitate,

Amor, nuova, ed antica vanitate,

I89:M69

Amor, io chero mia donna in domino,

G

I89:M69

Loffo Bonaguida

Provato ho assai Madonna di ciausire

Provato ho assai, Madonna, di ciausire

G

G96

Ser Onesto Bolognese

La partenza, che foe dolorosa

La partenza, che foe dolorosa

OR74

Quella crudel stagione, che a giudicare

G

OR74

Non so, s'è merce, che mi vene a meno,

A

OR74

La dispietata, che m'ha giunto il giovi

M. Guido Guinizzelli da Bologna

A'l cor gentil ripara sempre Amore,

\begin{tabular}{|c|c|c|}
\hline Al cor gentil ripara sempre Amore, & G & M69 \\
\hline Avvegnachè del maggio più per tempo & A & $\begin{array}{l}\text { not in SG86 } \\
\text { or M69 }\end{array}$ \\
\hline Donna, l'amor mi sforza, & $\mathrm{BM}$ & M69 \\
\hline In quelle parti sotto tramontana & $\mathrm{BM}$ & $\begin{array}{l}\text { not in SG86 } \\
\text { or M69 }\end{array}$ \\
\hline Lo vostro bel salute, e gentil guardo & $\mathrm{BM}$ & M69 \\
\hline Veduto ho la lucente stella Diana, & $\mathrm{BM}$ & M69 \\
\hline Io vo' dal ver la mia donna laudare & $\mathrm{BM}$ & M69 \\
\hline Dolente, lasso, già non m'assicuro & $\mathrm{BM}$ & M69 \\
\hline Lamentoni di mia disavventura, & $\mathrm{BM}$ & M69 \\
\hline
\end{tabular}


Table 2. (continued)

\begin{tabular}{|c|c|c|c|}
\hline Giuntina 1532 & Seghezzi's expanded edition & $\begin{array}{l}\text { His } \\
\text { Source }\end{array}$ & $\begin{array}{l}\text { Modern } \\
\text { Edition }\end{array}$ \\
\hline \multicolumn{4}{|l|}{ Bonagiunta Urbiciani da Lucca } \\
\hline \multirow[t]{6}{*}{ Ben mi credea in tutto esser d'Amore } & Ben mi credea in tutto esser d'Amore & G & Z15; SA68 \\
\hline & Qual uomo è in su la rota per ventura & BM & Z15; SA68 \\
\hline & Chi va cherendo guerra, e lassa pace, & $\mathrm{BM}$ & $\mathrm{Z15}$ \\
\hline & Movo di basso, e voglio alto montare, & $\mathrm{BM}$ & $\mathrm{Z} 15$ \\
\hline & Gli vostri occhi, che m'hanno divisi & $\mathrm{BM}$ & $\mathrm{Z16}$ \\
\hline & Con sicurtà dirò, poich'io son vostro & $\mathrm{BM}$ & C60 \\
\hline \multicolumn{4}{|l|}{ Notajo Jacopo da Lentino } \\
\hline \multirow[t]{16}{*}{ Madonna dir vi vollio } & Madonna dir vi voglio, & $\mathrm{G}$ & A08 \\
\hline & Amando lungiamente, & A & A08 \\
\hline & L'amor, da cui si muove, e tuttor viene & A & A08 (false) $)^{26}$ \\
\hline & In un gravoso affanno & A & A08 (false) $)^{27}$ \\
\hline & Maravigliosamente & A & A08 \\
\hline & Membrando cio, che Amore & A & A08 (false) $)^{28}$ \\
\hline & Chi non avesse mai veduto foco, & A & A08 \\
\hline & Guardando il basilisco venenoso, & A & $\begin{array}{l}\text { A08 } \\
\text { (dubbie) }^{29}\end{array}$ \\
\hline & Per gli occhi miei una donna, ed Amore & A & $\mathrm{D} 86^{30}$ \\
\hline & Siccome 'l sol, che manda la sua spera, & A & A08 \\
\hline & Ora mi puote si gran donna entrare & A & A08 \\
\hline & Amore è un disio, che vien dal core, & A & A08 \\
\hline & Molti amadori la lor malattia & A & A08 \\
\hline & Tanto sono temente e vergognoso & A & $\begin{array}{l}\text { A08 } \\
(\text { anonimo })^{31}\end{array}$ \\
\hline & Donne, vostra sembianti mi mostraro & A & A08 \\
\hline & Io m'aggio posto in core a Dio servire & A & A08 \\
\hline \multicolumn{4}{|l|}{ Guido delle Colonne } \\
\hline \multicolumn{4}{|l|}{ Piero delle Vigne } \\
\hline \multirow[t]{3}{*}{ Uno possente squardo } & Uno possente squardo & G & A08 \\
\hline & Perocchè amore non si può vedere, & A & A08 \\
\hline & Amore, in cui io vivo, ed ho fidanza & $\mathrm{BM}$ & A08 \\
\hline
\end{tabular}

26. Antonelli et al. 2008 (2: 285-97) attributes this poem to Piero della Vigna.

27. Antonelli et al. 2008 (2: 154-62) attributes In un gravoso affanno to Rinaldo D'Aquino.

28. Antonelli et al. 2008 (3: 292-303) attributes Membrando ciò, ch'Amore to Guglielmo Beroardi.

29. Antonelli et al. 2008 (1:589-95) places this poem in the section "Dubbie attribuzioni".

30. De Robertis 1986 (234-35) attributes this poem to Iacopo Cavalcanti.

31. Antonelli et al. 2008 (3: 881-83) includes this sonnet in the section of "anonimi siculo-toscani". 


\begin{tabular}{llll}
\hline Giuntina 1532 & Seghezzi's expanded edition & $\begin{array}{l}\text { His } \\
\text { Source }\end{array}$ & $\begin{array}{l}\text { Modern } \\
\text { Edition }\end{array}$ \\
\hline $\begin{array}{l}\text { Re Enzo } \\
\text { S'eo trovasse pietanza }\end{array}$ & $\begin{array}{l}\text { S'eo trovasse pietanza } \\
\text { Tempo vene, che sale, e chi discende: }\end{array}$ & G & A08 \\
$\begin{array}{l}\text { Imperadore Federigo II } \\
\text { Poi chè ti piace Amore, }\end{array}$ & Poichè ti piace, Amore, & G & A08 \\
\hline
\end{tabular}

Seghezzi's Sources

$\mathrm{G}=$ Giuntina

A $=$ Allacci

$\mathrm{BM}=$ La bella mano

$\mathrm{CR}=$ Crescimbeni's Istoria

\section{Modern Editions}

Antonelli, I poeti della scuola siciliana, 2008. (A08)

Contini, Poeti del Duecento, 1960. (C60)

De Robertis, ed., Guido Cavalcanti, Rime: con le rime di Iacopo Cavalcanti, 1986. (D86)

Gambino, Noffo, "Le rime di Noffo Bonaguide", 1996. (G96)

Iovine, ed., Lapo Gianni, Rime, 1989. (I89)

Marti, Poeti del Dolce Stil Novo, 1969 (M69)

Orlando, Le rime di Onesto da Bologna, 1974. (OR74)

Salinari, La poesia lirica del Duecento, 1968. (SA68)

Sanguineti, Guinizzelli, Poesie, 1986. (SG86)

Sapegno, Poeti minori del Trecento, 1952. (S52)

Zaccagnini \& Parducci, Rimatori siculo-toscani del Dugento, 1915 (Z15)

For those poets who did not have extensive collections in print to draw from, we can see the results. Seghezzi does not add any poems for Franceschino degli Albizi, Loffo Bonaguida (also known as Noffo, short for Arnolfo) or Guido delle Colonne. Those who received only one additional poem include Ser Lapo (Amor, io chero mia donna in domino taken from Allacci) and Re Enzo (Tempo vene, chi sale, e chi discende from Crescimbeni). He adds a sonnet and a canzone to Pier delle Vigne's works and three sonnets to Onesto Bolognese's corpus (from Allacci). In some cases, Seghezzi did not utilize as many poems as he could have from Allacci's collection, perhaps seeing them as corrupt or unflattering to the poets. For example, he chose not to add Guido delle Colonne's La mia gran pena e lo grauoso affanno nor Gioiosamente canto from Allacci $(1661,421-3)$. By the same token, even for Onesto Bolognese, he did not add Quel che per lo caval perde la mescola nor Voggio saggio parlar che manifesto from Allacci (1661, 396-97).

32. Antonelli et al. 2008 (2: 728) questions the attestation for S'eo trovasse pietanza: "Re Enzo/Semprebene?". 
The five sonnets he added by Bonagiunta appear in the same order as they are found in La bella mano. Later in Book Twelve, Seghezzi added two poems Bonagiunta addressed to other poets. There were only three other poems by Bonagiunta in La bella mano that Seghezzi could have added and chose not to: Un arbor folgorato, Deh che fera pesanza, and Copula amistanza generale ( $\mathrm{La}$ bella mano, 1715, 173-5). Bonagiunta is not featured in Allacci's collection.

Seghezzi's significant addition of poems by Fazio degli Uberti is mentioned in the preface. From Allacci's collection, he added Fazio's cycle of sonnets on the seven cardinal sins; the only poems by Fazio in that collection. He also reprinted the two poems by Fazio from La bella mano: the canzone Io guardo infra l'erbette per li prati and the sonnet Per me credea, che 'l suo forte arco Amore, addressed to Antonio da Ferrara. Strangely, he did not include Antonio's response.

Notably, Seghezzi added eight poems by Guinizzelli (three canzoni and five sonnets) to his edition. As seen in the table above, he copies Avvegnachè del maggio più per tempo alone from Allacci $(1661,377)$, while the seven other poems were taken from La bella mano in the very same order that they appear in that collection.

In the case of Giacomo da Lentini, we have perhaps one of Seghezzi's most explicit efforts in promotion of a canon. The additions of Giacomo's poetry far outnumber those made to other poets in this section. He added fifteen poems by Lentini, five canzoni and ten sonnets, to the already existing Madonna dir vo voglio. The 1715 Bella mano di Giusto de' Conti only contains one poem by "Jacomo da Lentino", Chi non avesse mai veduto foco, so Seghezzi had to turn to Allacci, an editor he did not fully trust. Granted, in Allacci, there are 30 poems attributed to Giacomo da Lentini (AllacCI 1661,$398 ; 426-81$ ), and Seghezzi's decision to use half of these seems to demonstrate that he was rather cautious in his willingness to accept Allacci's attributions. The upcoming section in my paper on orthography shows how much Seghezzi updated the language of his additions to Lentini and partially explains why he was selective here.

Seghezzi's attributions were not so inaccurate. As shown on the table above, Antonelli attributes nine of these to Lentini, lists one as a dubious attribution, and three as false. Antonelli does not mention Per gli occhi miei una donna, ed Amore, even as a poem of dubious or false attribution to Lentini, but he does place Tanto sono temente e vergognoso in the section 'Anonimi siciliani' (2008, 3: 881-3).

Remarkably, like compilers of manuscripts in the medieval times, Seghezzi took poems from Allacci in blocks (see Table 3). This does not necessarily support the idea that he chose the most important poems by Giacomo found in Allacci. 
Table 3. The order of poems by Giacomo da Lentini as presented in the anthologies of Leone Allacci and Anton Federigo Seghezzi

Allacci's Poeti Antichi (1661) Seghezzi's additions to the Giuntina (1731)

Amando lungiamente

Amor dacchui si move tuttora e vene

Poi tanta canoscenza

In un gravoso affanno

Maravigliosamente

Membrando cio che amore

Chi non havesse mai veduto foco

Guardando il Basilisco velenoso

Per gli ochi mei una donna $\mathbb{E}$ amore

Amor gli occhi di costei mi fanno

Feruto sono isvariatamente

Cotale gioco mai non fu veduto

Lo gilglio quand e colto tosto passo

Si come il sole che manda la sua spera

Ora me pote si gran donna entrare

Molti amadori la loro malatia

Tanto sono temente, e vergognoso

Donna vostri sembianti mi mostraro

Io magio posto in core a' Dio servire

Segnori udite strano maleficio

Amor $m$ accid. Perche? Perch'io amo

La namoranza disiosa

Ben m'e' venuta prima al cor doglianza

Donna eo languisco, e no' so qua speràza

Dolce cominciamento

Amor non vol ch io clami

Dal cor mi vene

Troppo son dimorato

Guidardone aspetto havere

Note: The right column lists the fifteen poems by Giacomo da Lentini that Seghezzi added to the original Giuntina which features Madonna dir vi voglio.

33. In Allacci 1661, this poem appears much earlier in the volume than the others by Giacomo da Lentini, as it is part of a tenzone with Jacopo Mostacci and Piero della Vigna (398).
Amando lungiamente

L'Amor, da cui si muove, e tuttor viene

In un gravoso affanno

Maravigliosamente

Membrando ciò, che Amore

Chi non avesse mai veduto foco

Guardando il basilisco venenosa

Per gli occhi miei una donna, ed Amore

Siccome 'l sol, che manda la sua spera

Ora mi puote sì gran donna entrare

Amore è un disio, che vien dal core $e^{33}$

Molti amadori la lor malattia

Tanti sono temente, e vergognoso

Donna, vostri sembianti mi mostraro

Io m'aggio posto in core a Dio servire 
Seghezzi did not utilize any of the last nine poems in Allacci's edition attributed to Giacomo da Lentini, nor the last three attributed to Bonagiunta, nor the last two to Onesto Bolognese. We thus can conjecture that he might have believed that Allacci placed the least reliable, or perhaps the least important, last.

\section{Book Twelve: Tenzoni}

Seghezzi names his edition's new Book Twelve: "Canzoni antiche di autori incerti e sonetti di diversi, mandate l'uno all'altro". This new title is a combination of two titles found in books Ten and Eleven of the original Giuntina. Of the thirteen canzoni of uncertain attribution, Seghezzi only maintains two of them as anonymous. By attributing nine canzoni to Dante and two to Cino, Seghezzi faces the decision of what to do with the two remaining canzoni of uncertain attribution. He demonstrates his respect for the original Giuntina by maintaining these two poems $(\mathrm{Nel}$ tempo, che si'nfiora e copre d'erba and O patria degna di trionfal fama), as well as the two sestine (Amor mi mena tal fiata a l'ombra and Gran nobiltà mi par vedere a l'ombra) even as he runs the risk of having a textual imbalance in his "corrected edition".

Seghezzi's Book Twelve keeps the 31 sonnets of the Giuntina's Book Eleven in the same order and adds the following eleven poems to the end of the book (see Table 4). He did not add any new poets to this section.

Table 4. The eleven poems that Seghezzi added to Book Eleven of the Giuntina (featured at the end of Seghezzi's Book Twelve)

\begin{tabular}{lll}
\hline Sender and Addressee & Incipit & $\begin{array}{l}\text { Sources listed in } \\
\text { Seghezzi's glosses }\end{array}$ \\
\hline $\begin{array}{l}\text { Cino a Dante } \\
\text { Cino a Dante }\end{array}$ & $\begin{array}{l}\text { Signor, è non passò mai peregrino } \\
\text { Dante, io ho preso l' abito di doglia }\end{array}$ & Pilli \\
$\begin{array}{l}\text { M. Onesto Bolognese a M. Cino Da } \\
\text { Pistoia }\end{array}$ & $\begin{array}{l}\text { Siete voi, Messer Cin, se ben vi adocchio } \\
\text { Risposta di M. Cino }\end{array}$ & Bella mano \\
$\begin{array}{l}\text { Bonaggiunta Urbiciani a Guido } \\
\text { Cavalcanti }\end{array}$ & $\begin{array}{l}\text { Io son colui, che spesso m'inginocchio } \\
\text { Risposta di Guido Cavete mutata maniera }\end{array}$ & Bella mano \\
& Uomo, ch'è saggio, non corre leggero & $\begin{array}{l}\text { Seghezzi incorrecly states } \\
\text { that Allacci attributed } \\
\text { this Guinizzelli }\end{array}$ \\
Bonaggiunta a Guido Cavalcanti & Chi se medesimo inganna per neghienza &
\end{tabular}


Table 4. (continued)

\begin{tabular}{|c|c|c|}
\hline Sender and Addressee & Incipit & $\begin{array}{l}\text { Sources listed in } \\
\text { Seghezzi's glosses }\end{array}$ \\
\hline Guido Orlandi a Guido Cavalcanti & Onde si move, ed onde nasce amore? & $\begin{array}{l}\text { dal comento di Fr. Paolo } \\
\text { del Sross sopra la Canzone } \\
\text { del Cavalcanti Firenze } \\
1568\end{array}$ \\
\hline $\begin{array}{l}\text { Guido Cavalcanti a Guido Orlandi } \\
\text { Risposta di G. Orlandi }\end{array}$ & $\begin{array}{l}\text { La bella donna, dove amor si mostra } \\
\text { Innanzi al suon di trombe che di corno }\end{array}$ & Bella mano \\
\hline M. Onesto Bolognese a Fra Guittone & Vostro saggio parlar, ch'è manifesto & Allacci \\
\hline
\end{tabular}
D'Arezzo

Though Seghezzi's glosses do not mention the source for each grouping, all but the first and the last of these poems are found in La bella mano. He incorrectly attributes the famous sonnet Uomo, ch'e' saggio non corre leggero to Guido Cavalcanti, instead of to Guido Guinizzelli. ${ }^{34}$ His gloss wrongly states as well that Allacci attributes it to Guinizzelli, when in truth Allacci had assigned it to Guittone d'Arezzo $(1661,388) .^{35}$

34. In the 1715 reprint of La bella mano, Bonagiunta's sonnet Poichè avete mutate maniera is presented as "Bonagiunta Orbiciani da Lucca al detto M. Guido" (220-21) and the only header before Uomo, ch'e' saggio, non corre leggero is "risposta". Seghezzi here obviously interprets the attribution "M[esser] Guido" as referring to Guido Cavalcanti. Neither Favati (1957) nor De Robertis (1986) attribute the poem to Cavalcanti. EDwards lists the manuscripts in which Omo ch'è saggio non corre leggero is attributed to Guinizzelli: Vatican, MSS Chigiano L viii 305, Latino 3793, Latino 3214; Firenze, Laurenziano Rediano 9; Firenze, Biblioteca nazionale, MSS Magliabechiano 1208, Magliabechiano 1060, Palatino 753 (c. 216) (Edwards 1987, 142).

35. Unfortunately, Seghezzi's simple gloss does not provide any information on how he arrived at this attribution. Edwards also lists $(1987,142)$ the instances in which Uomo, ch'e' saggio non corre leggero is attributed to others: to Guittone D'Arezzo in Vatican, Barberiniano Latino 3953; to Francesco [?] in Firenze, Biblioteca Riccardiana 1103. Often copied in various semesters of the Memoriali bolognesi, the poem is by practice in the notarial registers "anonymous", as it is as well in MS Firenze, Biblioteca nazionale, Magliabechiano VII, 1060. The attribution to Guittone by Allacci, librarian of the Vatican and also of the Barberini Library, is likely explained by his access to Barberianiano Latino 3953. An early editor of Cavalcanti's lyric poetry, Antonio Cicciaporci (Rime, 1813) challenges Seghezzi's attributions, arguing that the Zane edition (1740, edited by Seghezzi) wrongly places the sonnet L'anima mia vilmente è sbigottita by Cavalcanti "tra le Rime di Cino da Pistoia". Cicciaporci corrects Seghezzi, pointing out that "Lo stesso Zane a pag. 356. attribuisce a Guido Cavalcanti quel Sonetto, 
Apart from his methodological mysteries, we can conjecture that Seghezzi was possibly interested in elevating Cavalcanti's role in his edition and the canon, presenting him as the key Stilnovist who introduced a new poetics and poetic language to the landscape of early Italian literature. Of the eleven poems added to his book, three are attributed as being addressed to Cavalcanti and two are attributed to him as his responses. ${ }^{36}$ While Cavalcanti was already a key figure in the section of "tenzoni" (literary debates) of the original 1527 Giuntina, in which three sonnets are attributed to him, Seghezzi strengthens Cavalcanti's historical role, as well as that of Cino's among the early poets. ${ }^{37}$

\section{Orthography and Punctuation}

Throughout his edition, Seghezzi attempts to make the poems more accessible to his contemporary readers by altering and "modernizing" the poems' orthography and punctuation. His changes to the poems in the original Giuntina are not nearly as drastic as those he added from Allacci's collection. A standard intervention of Seghezzi's was to eliminate the letter "h" in various conjugated forms of the verb avere (such as havesse, havea, etc.). He also eliminated the " $h$ " from forms such as tutthor, and also from proper nouns such as Honesto, as in the case of Onesto Bolognese.

Seghezzi favored geminates in various cases, transforming words such as Provedenza to Provvedenza, or preferring provvedere rather than provedere. At times, he eliminated cases of the "rima siciliana", as he did in the first quartrain of the sonnet Quella; che in cor l'amorosa radice addressed from Onesto to Cino:

Giuntina (1532 edition)

Quella; che in cor l'amorosa radice Mi piantò ne'l primier, che mal la vidi; Cioè la dispietata ingannatrice; A morir m'ha condotto; e tu no'l credi.

\author{
Seghezzi (1740) \\ Quella, che in cor 1 amorosa radice \\ Mi piantò nel primier, che mal la vidi, \\ Cioè la dispietata ingannatrice; \\ A morir m'ha condotto, e tu nol cridi.
}

che comincia 'Uomo, ch'e' saggio, non corre leggerò [. . . ] ma si' nell'Allacci, che nella Bella Mano di Giusto de' Conti è dato a Guido Guinizzelli, come ancora nel Cod. 1208 della Magliabech. Classe VII. Var. Palchetto 7" (1813, 127).

36. The source for one of his responses, the one to Guido Orlandi, La bella donna, dove amor si mostra is La bella mano. Favati and De Robertis attribute La bella donna, dove amor si mostra to Cavalcanti (tenzone con Guido Orlandi). See De Robertis 1986, 193.

37. Seghezzi added two sonnets addressed to Dante by Cino da Pistoia and one of Cino's responses to Onesto Bolognese. 
One form that Seghezzi did not accept from the Giuntina was the graphic use of "ll" in cases where the by-then standardized palatal form of "gl" would apply. At the beginning of Giacomo da Lentini's famous canzone in the Giuntina, we see two instances of this in vollio and orgollio, which Seghezzi changes to voglio and orgoglio:

Giuntina (1532 edition)

Madonna dir vi vollio, Come l'Amor m'ha priso In ver lo grande orgollio,
Seghezzi, ed. (1740)

Madonna dir vi voglio,

Come l'Amor m'ha priso

In ver lo grande orgoglio

However, one can only find slight differences in the rest of the poem in the two editions. Indeed, Seghezzi accepted most of the orthographic forms supplied by the Giuntina's Tuscan printers, the Giunti. Leone Allacci, born in Greece but raised in Rome, did not Tuscanize the orthography of poems in his 1661 edition of Poeti antichi in the same way that the Giunti brothers did.

A starting point to see how Seghezzi modernized his additions is to analyze the poems of Giacomo da Lentini taken by Seghezzi from Allacci's collection. First, Giacomo's sonnets in Allacci demonstrate a minimal use of commas and apostrophes. Seghezzi intervened by placing numerous commas, semicolons, and colons to mark varying lengths of pauses. Second, Seghezzi favored the dipthongization of conjugated forms of verbs, such as venire, tenere, and convenire. Still, Seghezzi chose not to dipthongize words like foco and loco (rather than fuoco and luogo). Third, as we have already noted, Seghezzi preference for geminates (rottura rather than rotura, coraggioso instead of coragioso) distinguished his editorial approach from that of Allacci's. Fourth, Seghezzi changed Latinisms such as the consonant cluster - $c t$ to - $t$ in past participles like fatto (rather than facto).

As we can see, for example, in Giacomo da Lentini's Io m'aggio posto in core a Dio servire, Seghezzi not only made changes in punctuation, adding numerous commas and several apostrophes, but he instituted even more radical changes, insisting for example on the corrective application of "perfect hendecasyllables" (verses 4, 5, 6, 11, 13). He also made grammatical changes, such as specifying the 1st person subjunctive in verses 2 and 10. The Latinism audito is modernized to udito and the Old Provençal forms of blonda and claro are changed to their Tuscan equivalents that include dipthongs. In the first verse, Seghezzi did not change the Siculo-Tuscan form of the first person of the verb avere (aggio), other than correct it with a geminate and apostrophe to mark elision, but he did change the literarySicilian form of vegendo to vedendo (v. 14). Seghezzi also tends to modernize preposition + definite article, such as da la, to dalla (v. 8): 
Allacci, ed. 1661, 454

Seghezzi, ed. 1740, 320-1

Io magio posto in core à Dio servire

Io m'aggio posto in core a Dio servire, Com'io potesse gire in Paradiso Com'io potessi gire in paradiso, $\mathrm{Al}$ santo loco c agio audito dire Al santo loco, ch'aggio udito dire,

Ove si mantiene sollazo gioco e riso

U' sì mantien sollazzo, gioco, e riso.

Senza la mia Donna non vi vorria gire

Senza la donna non vi vorria gire, Quella ca la blonda resta el claro viso Quella, c'ha bionda testa, e chiaro viso; Che senza lei non porzeria gaudire Che senza lei non poteria gaudire, Estando da la mia donna diviso.

Restando dalla mia donna diviso;

Ma non lo dico a tale intendimento

Ma non lo dico a tale intendimento, Perch io peccato ci vollesse fare

Se non vedere lo suo bello portamento

Perch'io peccato ci volessi fare,

Se non veder lo suo bel portamento,

E lo bello viso el morbido sguardare Che lo mi tiria in grande consolamento Vegendo la mia donna in gioia stare.

E lo bel viso, e il morbido guardare; Che 'l mi terria in gran consolamento, Vedendo la mia Donna in gioia stare.

Allacci was not the only source of poems that Seghezzi utilized and corrected. In the following table, we can see how Seghezzi also turned to Crescimbeni as his source for Tempo vene, che sale, e chi discende. Seghezzi trusted Crescimbeni's attribution of this sonnet to Re Enzo over Allacci's claim that it belonged to Guittone d'Arezzo. Nonetheless, Seghezzi maintained his editorial principles of modernization and standardization of the language. The orthography of the version in Crescimbeni is a direct transcription from Vat. Lat. 3214, Bembo's manuscript of early Italian poems. ${ }^{38}$ Seghezzi, for the most part, respected the versification of this version, but he curiously decided to extend the use of anaphora in the second quatrain, using the conjunction $E$ two additional times in verses 5 and 7 to "perfect" the hendecasyllable rhymes. He also turned to Allacci to improve the hendecasyllable in verses 10 and 11 . For the beginning of verse 10, he transforms Cului into Colui possibly to clarify the subject of the verse. In verse 11, he adopted "E che col tempo" from Allacci, instead of using "E col tempo".

38. See Pelaez 1895, 83. 


\begin{tabular}{|c|c|c|}
\hline $\begin{array}{l}\text { Allacci, ed, } 1661,390 \\
\text { (attr. to Guittone) }\end{array}$ & Crescimbeni, 1730 , vol. 3,38 & $\begin{array}{l}\text { Seghezzi, ed. } 1740,328 \\
\text { (attr. to Re Enzo) }\end{array}$ \\
\hline Tempo ven che sale, e che sendere & Tempo vene ki sale e ki discende & Tempo vene, chi sale, e chi discend \\
\hline E tempo e di parlare e tacere & Tempo e da parlare e da taciere & E tempo è da parlare, e da tacere: \\
\hline E tempo di scoltare e d'imprendere & Tempo e dascoltare e da inprende & E tempo è da ascoltare, e d'apprende \\
\hline E tempo di molte cose provedere & Tempo da minaccie non temere. & E tempo da minaccie non temere. \\
\hline E tempo e da venzar, e d ofendere & Tempo dubbidir kitti inprende & E tempo d'ubbidire chi t'imprende; \\
\hline E tempo di menaze non temere & Tempo di molte cose provedere & Tempo di molte cose provvedere: \\
\hline E tempo e d ubedir e reprendere & Tempo di veghiare kittoffende & E tempo di venghiare chi t'offende: \\
\hline E tempo d'infinzer non vedere & Tempo di fignere di non vedere. & Tempo di fingere di non vedere. \\
\hline Pero lo tengo sazo, e cognoscente & Pero lo tegno saggio e canosciente & Però io tengo saggio e canoscente \\
\hline Cului che fa sui fati cun rasone & Que ke fa i facti con ragione & Colui, che fa suoi fatti con ragione, \\
\hline E che col tempo si sa comportare & E col tempo si sa comportare & E che col tempo si sa comportare: \\
\hline E chi si mette nel plazer de la zente & E mettesi in piacer de la gente & E mettesi in piacere della gente, \\
\hline Che no se trovi alcuna rasone & Ke non si trovi nessuna cagione & Che non si trovi nessuna cagione, \\
\hline Che sol d un fato se possa blasmare. & Ke lo su facto possa biasimare. & Che lo suo fatto possa biasimare. \\
\hline
\end{tabular}

Seghezzi also updated the spelling and punctuation by adding accents, apostrophes to show elision and commas and colons to mark pauses. He alters the phonology of fignere to fingere and tegno to tengo. He prefers apprendere over imprendere, perhaps to stress the verse's alliteration. Again the Latinate form of facto is updated to fatto. Perhaps, the most obvious difference is the transformation of the thirteenth-century spelling, especially in the anthology MS Firenze, Biblioteca Nazionale, Banco Rari 217, of ke to che. ${ }^{39}$

\section{Additional Paratextual Features}

Seghezzi's interest in providing an expanded anthology for students can be seen in the volume's wider margins, which are more user-friendly for marginalia. Another reader-friendly paratextual feature of Seghezzi's edition is the principle of printing two sonnets per page in Book Twelve, dedicated to the literary debates, or "tenzoni" ${ }^{40}$ Seghezzi did not, however, apply this

39. Bruno Migliorini $(1989,484)$ notes that in Seghezzi's Settecento "Nessuna traccia si ha più di $k$ se non nel vocabolario kavaliere a Venezia".

40. On the first page of Book Twelve, there is only one sonnet, Cino da Pistoia's Naturalmente chere ogni amadore in response to Dante's sonnet A ciascun alma presa, e gentil core found at the opening of Book One. For the rest of Book Twelve until the penultimate page ([seghezzi] 1740, 339-58), the "debate son- 
principle throughout his edition. Book Eleven in the 1532 edition, dedicated to the tenzoni, does not follow the two-sonnets-per-page format. The main reason for this is that the two sonnets barely fit per page in this smaller book and with the additional information needed to present the authors and recipients of the tenzoni, too many lines are taken up. There are some stretches in the 1532 Giuntina that include two sonnets per page, a long one in Book V on Cino (Rime di diversi antichi autori toscani. 1532, cc. 50v-60r), but this was not a principle for that edition either.

Seghezzi added a helpful index at the end of his edition (not a feature of the 1532 edition). On page 360, Seghezzi's edition lists names of poets in alphabetical order and it notes the page numbers where series of poems by these authors begin. The index of incipits for the 424 poems in the edition is in alphabetical order. It begins with the sonnet A ciascun' alma presa, $e$ gentil core and ends with Usato avea lungo temporale.

Unlike the 1532 Giuntina, Seghezzi's edition does not feature section markers that specify changes in the genres of poems. The 1532 edition does not always label the sections of BALLATE, for example, but it does frequently mark the sections of the longer poetic forms of CANZONI. ${ }^{41}$ Also in the 1532 edition's Book Nine ("Canzoni e ballate di diversi autori"), each poem has a header specifying the genre. For example, the first poem is introduced as "Ballata di Franceshino degli Albizi".

Finally we should note that Seghezzi uses larger black initials for 'capilettere' of the first poems in each book, whereas the 1532 edition leaves a space of roughly $1.5 \mathrm{~cm} \times 1.5 \mathrm{~cm}$ for illustration. Seghezzi does not maintain the practice of having uppercased letters in bold at the beginning of each stanza of canzoni, and at the beginning of quartine and terzine in the sonnets, which he likely viewed as unnecessary.

\section{Conclusion}

Eight years after publishing his expanded edition of the Giuntina, Seghezzi expressed frustration that his efforts to enlighten the young, by sharing the great works of Italian medieval poets, did not yield noteworthy results:

nets", in tenzone, are presented together two-per-page. Elsewhere in his edition, more often than not, sonnets carry over from one page to another.

41. For example, it does not have a header for BALLATE in Book V, but it does in Book VI. 
Mi ricorda ancora sdegnosamente, quando avendo io fatto ristampare le Rime antiche di vari Autori, accresciute di tante giunte da me con somma fatica raunate, appena uscito il libro rimase sepolto: non avendo la gioventù voluto conoscere il pregio di quel volume, che è ripieno di novelli pensieri, e d'una certa natural soavità, che ne' secoli appresso più non s'udì. Ma ci sono alcuni, che incontrando una voce alquanto aspra alle orecchie, adombrano e raccapricciano, come fanciullo, a cui la balia, per prendersi diletto, faccia veder qualche ceffo mostruoso. $(1739,5 \mathrm{r}-\mathrm{v})$

Despite his frustration, Seghezzi's agenda remained constant over his brief years of fruitful activity and exemplified Arcadian tastes. His significant additions to Dante, Cino, Cavalcanti, Guinizzelli and Giacomo da Lentini illustrate his desire to increase their prominence as part of an elite canon; an objective he would also seek to obtain for the Renaissance writers Bernardo Tasso, Annibal Caro and Galeazzo di Tarsia. His career-long agenda to promote a canon, also seen in his curation of works by Torquato Tasso, Angelo di Costanzo and Pietro Bembo, was largely a response to the ongoing debate between French and Italian critics over which literary tradition was stronger.

Adding material and making his editions user-friendly were two key elements of his agenda in the promotion of his ideal canon. A user-friendly edition would be more likely to encourage readers to study these essential poets. For Seghezzi the best vehicle upon which to build his own anthology was the 1527 Giuntina print edition, whose structure already promoted literary principles and works he valued. He applied a number of specific editorial principles to the Giuntina project which demonstrated his respect for the original collection: he did not discard the Giuntina's existing poems, he did not add any poets not already featured in the original Giuntina and he followed the Giuntina's arrangement by genre in those cases when he did add poems to existing books. Seghezzi also respected the spirit of the original Giuntina by bolstering the Giuntina's featured Stilnovist poets (Dante, Cino and Cavalcanti), and he was careful not to add "corrupt" works that did not seem fitting to the prized anthology. Several of his principles beyond these reflect, however, a more aggressive editorial intervention: he chose to elevate the position of certain Sicilian and Tuscan poets in the collection, he attempted to reduce uncertainty by reassigning poems to Dante and Cino from the Giuntina's book of "autori incerti" and he brought the orthography of poems he added to the collection more into line with his then more modern views of punctuation. At the same time, Seghezzi tended not to follow the original Giuntina's use of genre headings 
to mark internal divisions among books. Nor does Seghezzi offer detailed explanations of his methods for determining attributions, nor does he shed much light on the ancient manuscripts he consulted and only casually mentioned in his book on Dante.

Certainly, Seghezzi's fervent activity and editorial principles are illuminating in a pivotal moment of print history in Italy, when Italian literary critics and publishers felt challenged to defend their canon and, at the same time, promote new writers. Reprints abounded during this period, as exemplified with three reprintings the Giuntina from 1727 to 1740 . Seghezzi, the trusted editor for the Volpi brothers and close friend of Apostolo Zeno, was for fifteen years one of the principal proponents in the development of the Italian canon. Well respected during his time, Seghezzi garnered attention in the decade leading up to the unification of Italy, when in 1850 Paravia published his biography. While his expansion of the Giuntina and his methods of attribution do not match the standards of critical editions today, Seghezzi's work stands as one of the cornerstones of print history in early eighteenth-century Italy and the Italian literary canon.

University of Kansas

\section{Works Cited}

[Aletino, Afoto], ed. 1727. Sonetti, e canzoni di diversi antichi autori toscani in dieci libri raccolte. Firenze: Elaumene Loppagi.

Allacci, Leone, ed. 1661. Poeti antichi. Raccolti da codici MSS. della Biblioteca Vaticana e Barberina da Monsignor Leone Allacci. Napoli: Sebastiano d'Alecci.

Antonelli, Roberto, Costanzo Di Girolamo and Rosario Coluccia, eds. 2008. I poeti della scuola siciliana. 3 vols. Milano: Mondadori.

Arato, Franco. 2002. La storiografia letteraria nel Settecento italiano. Pisa: Edizioni ETS.

Baldacchini, Lorenzo. 2003. "COMINO, Giuseppe". Dizionario biografico degli italiani. Vol. 27 (Collenuccio-Confortini). Roma: Istituto della Enciclopedia Italiana.

Bindi, Enrico and Pietro Fanfani, eds. 1878. Le rime di Messer Cino da Pistoia. Pistoia: Tipografia Niccolai.

Brand, Peter and Lino Pertile, eds. 1996. The Cambridge History of Italian Literature. Cambridge, UK: Cambridge University Press.

Bruni, Francesco. 2010. Italia. Vita e avventure di un'idea. Bologna: Il Mulino.

Caesar, Ann Hallamore and Michael Caesar. 2007. Modern Italian Literature. Cambridge, UK: Polity Press.

Cicciaporci, Antonio. ed. 1813. Rime di Guido Cavalcanti, edite ed inedite. Firenze: Niccolò Carli. 
Considerazioni del marchese Giovan-Gioseffo Orsi Bolognese Sopra la maniera di ben pensare ne' componimenti, già pubblicata dal Padre Dominico Bouhours [. . .] S'aggiungono tutte le Scritture, che in occasione di questa letteraria Contesa uscirono a favore e contro al detto Marchese Orsi. 1735. 2 vols. Modena: appresso Bartolomeo Soliani.

Contini, Gianfranco, ed. 1946. Dante Alighieri, Rime. Rpt; 1st ed. Torino: Einuadi. , ed. 1960. Poeti del Duecento. 2 vols. Napoli: Ricciardi.

Crescimbeni, Giovanni Mario. 1730. L'istoria della volgar poesia. 6 vols. Annotations by Anton Federigo Seghezzi and Pier Caterino Zeno. Venezia: L. Basegio.

Debenedetti, Santorre. 1907. "Nuovi studi sulla Giuntina di Rime antiche”. Giornale storico della letteratura italiana 50: 281-340.

Delle opere di Torquato Tasso: con le controversie sopra la Gerusalemme liberata: e con le annotazioni intere di vari autori, notabilmente in questa impressione accresciute. 17351742. 12 vols. Venezia: Steffano Monti and N. N. Campagno.

De Michelis, Cesare. 1979. Letterati e lettori nel Settecento Veneziano. Firenze: Olschki.

De Robertis, Domenico, ed. 1977. Sonetti e canzoni di diversi antichi autori toscani (reprint). 2 vols. Firenze: Le Lettere.

—, ed. 1986. Guido Cavalcanti, Rime, con le rime di Iacopo Cavalcanti. Torino: Einaudi.

—, ed. 2002. Dante Alighieri, Rime. 5 vols. Firenze: Le Lettere.

Edwards, Robert, ed. 1987. The Poetry of Guido Guinizzelli. New York: Garland.

Favati, Guido, ed. 1957. Guido Cavalcanti, Rime. Milano: Ricciardi.

Federici, Fortunato. 1809. Annali della tipografia Volpi-Cominiana colle notizie intorno la vita e gli studi de' fratelli Volpi. Padova: Seminario.

Fraticelli, Pietro, ed. 1834. Poesie di Dante Alaghieri precedute da un discorso intorno alla loro legittimità. Firenze: Per Leop. Allegrini e G. Mazzoni.

Gamba da Bassano, Bartolomeo. 1839. Serie dei testi di lingua e di altre opere importanti nell'italiana letteratura scritte dal secolo XIV al XIX. Fourth Edition. Venezia: Co' tipi del Gondoliere.

Gambino, Francesca. 1996. "Le rime di Noffo Bonaguide". Studi di filologia italiana 54: 5-95.

Gorni, Guglielmo. 1978. "In margine alla Giuntina di rime antiche". Studi medievali 19: 899-911.

Infelise, Mario. 1989. L'editoria veneziana nel '700. Milano: Franco Angeli.

Iovine, Francesco, ed. 1989. Lapo Gianni, Rime. Roma: Bagatto Libri.

La bella mano di Giusto de' Conti Romano senatore e una raccolta di Rima antiche toscane. 1715. Reprint. Firenze: Per Jacopo Giudicci e Santi Franchi.

Marrone, Gaetana, Paola Puppa and Luca Somigli, eds. 2007. Encyclopedia of Italian Literary Studies. Vol. 1. New York: Routledge.

Marti, Mario, ed. 1969. Poeti del Dolce Stil Novo. Firenze: Le Monnier.

Mazzuchelli, Giammaria, 1760. Gli scrittori d'Italia. Cioè notizie storiche, e critiche intorno alle vite, e agli scritti dei letterati italiani del conte Giammaria Mazzuchelli. bresciano. Vol. 2, parte 2. Brescia: Giambatista Bossini.

Migliorini, Bruno. 1989. Storia della lingua italiana. Vol. 2. Firenze, Sansoni. 
Mussio, Thomas. 2007. "Ludovico Castelvetro", in Marrone, Gaetana, Paola Puppa, and Luca Somigli, eds. Encyclopedia of Italian Literary Studies. Vol. 1., 406-07. New York: Routledge.

Orlando, Sandro, ed. 1974. Le rime di Onesto da Bologna. Firenze: G. C. Sansoni.

Ottaviani, Alessandro. 2014. "Dentro e fuori l'Arcadia: la lirica di Giovanni Della Casa nella Repubblica delle lettere", in Beatrice Alfonzetti, Guido BaldasSARRI, and Franco TomAsi, eds. I cantieri dell'italianistica. Ricerca, didattica e organizzazione agli inizi del XXI secolo. Atti del XVII congresso dell'ADI - Associazione degli Italianisti (Roma Sapienza, 18-21 settembre 2013). Roma: Adi editore.

Paravia, Pier Alessandro. 1850. Vita e opere di Anton Federigo Seghezzi, in Memorie veneziane di lettere e di storia. Torino: Stamperia Reale.

Pelaez, Mario, ed. 1895. Rime antiche italiane secondo la lezione del codice Vaticano 3214 e del codice Casanatense d.v. 5. Bologna: Romagnoli dell'Acqua.

Pettas, William A. 1980. The Giunti of Florence: merchant publishers of the sixteenth century: with a checklist of all the books and documents published by the Giunti in Florence from 1497 to 1570, and with the texts of twenty-nine documents, from 1427 to the eighteenth century. San Francisco: Bernard M. Rosenthal.

Pon, Lisa and Craig Kallendorf, eds. 2009. The Books of Venice. New Castle, Delaware: Oak Knoll Press.

Richardson, Brian, 1994. Print Culture in Renaissance Italy: The Editor and the Vernacular Text, 1470-1600. Cambridge: Cambridge University Press.

Rime di diversi antichi autori toscani in dieci libri raccolte. 1532. Vinegia: Fratelli da Sabio.

Salinari, Carlo, ed. 1968. La poesia lirica del Duecento. 2d edition. Torino: Unione Tipografico-Editrice Torinese.

Sanguineti, Edoardo, ed. 1986. Guinizzelli, Poesie. Milano: Arnoldo Mondadori.

Santagata, Marco, ed. 2011. Dante Alighieri, Opere. Vol. 1. Milano: Mondadori.

SAn toro, Marco. 2008. Storia del libro italiano. Libro e società in Italia dal Quattrocento al nuovo millennio. Milano: Edizione bibliografica.

Sapegno, Natalino, ed. 1952. Poeti minori del Trecento. Napoli: Riccardo Ricciardi Editore.

[Seghezzi, Anton Federigo, ed.]. 1728. Il Tasso, Dialogo d'incerto, sopra lo stile di monsignor della Casa e il modo d'imitarlo in Tomo II delle Opere di monsignor Giovanni della Casa. Venezia: Appresso A. Pasinello.

[- ] ed. 1729. Pietro Bembo, Opere del cardinale Pietro Bembo: ora per la prima volta tutte in un corpo unite. . . 4 vols. Venezia: Francesco Hertzhauser.

[- ]. ed. 1731. Rime di diversi antichi autori toscani in dodici libri raccolte. Venezia: Cristoforo Zane.

1733a. "A' Lettori”. In Giornale de' Letterati d'Italia, Tomo 38. Venice: Hertz.

[-]. ed. 1733b. Delle lettere di M. Bernardo Tasso: accresciute, corrette, e illustrate: con la vita dell autore scritta dal Sig. Anton-Federigo Seghezzi: e con la giunta de' testimoni più notabili, e degl' indici copiosissimi. Vol. 1. Padova: Giuseppe Comino.

- 1735. La Vita del Commendatore Annibal Caro. In Delle Lettere Familiari del Commendatore Annibal Caro. Vol. 3. Padova: Giuseppe Comino. 
1739. "A' Lettori". In Novelle ventotto di messer Giovanni Boccaccio scelte ora la prima volta dal suo Decamerone: ad uso principalmente de' modesti giovani e studiosi della toscana favella: con la Descrizione della pestilenza stata in Firenze nel 1348. dello stesso autore: il tutto tratto con somma diligenza dagli ottimi testi. Padova: Giuseppe Comino.

[- ] ed. 1740. Rime di diversi antichi autori toscani in dodici libri raccolte. Venezia: Simone Occhi.

- 1744. "Prefazione postuma del Signor Anton Federigo Seghezzi", in L'Ercolano, dialogo di Benedetto Varchi nel quale si ragiona delle lingue, ed in particolare della toscana e della fiorentina: Colla correzione ad esso fatto da Messer Lodovico Castelvetro; e colla Varchina di Messer Girolamo Muzio. Padova: Giuseppe Comino.

- 1749. Opere volgari e latine di Anton Federigo Seghezzi aggiuntevi alcune rime di Niccolò suo fratello. Venezia: Pietro Bassaglia.

[-]. ed. 1750. Le rime di Angelo di Costanzo: si aggiungono le rime di Galeazzo di Tarsia. Padova: Giuseppe Comino.

[SEGNi, Bardo di Antonio], ed. 1527. Sonetti e canzoni di diversi antichi autori toscani in dieci libri raccolte. Firenze: Giunti.

Tissoni, Roberto. 1993. Il commento ai classici italiani nel Sette e nell'Ottocento (Dante e Petrarca). Padova: Antenore.

VAn der linden, Huub. 2008. "Apostolo Zeno as Reader and (Re)writer: Acknowledgement of Influence and Anxiety of Authorship". In Pon and Kallendorf 2009: 383-410.

Volpi, Giovanni Antonio and Gaetano Cristoforo Volpi, eds. 1733. Opere volgari, e latine del Conte Baldassare Castiglione. Padova: Giuseppe Comino.

West, Simon. 2009. The Selected Poetry of Guido Cavalcanti: A Critical English Edition. Leicester, UK: Troubador Publishing.

Zaccagnini, Guido and Amos Parducci, eds. 1915. Rimatori siculo-toscani del Dugento. Bari: Laterza. 